\title{
Studies Concerning the Usage of the Intrinsic Morphological and Chemical Features of Some Common and Document Paper Types as Security Items
}

\author{
ION PENCEA ${ }^{1}$, RAMONA NICOLETA TURCU1*, FLORIN MICULESCU ${ }^{1}$, CRISTIAN PREDESCU2, BRINDUS COMANESCU ${ }^{3}$ \\ ${ }^{1}$ Politehnica University of Bucharest, Materials Science and Engineering Faculty, Department of Materials Science and Physical \\ Metallurgy, 313 Splaiul Independentei, 060042, Bucharest, Romania \\ ${ }_{2}^{2}$ Politehnica University of Bucharest,Materials Science and Engineering Faculty, Department of Metallic Material Processing and \\ Ecometallurgy, 313 Splaiul Independentei, 060042, Bucharest, Romania \\ ${ }^{3}$ SC OPTOELECTRONICA 2001 SA, 409 Atomistilor Str., 77125, Magurele, Romania
}

\begin{abstract}
The paper addresses the usage of the intrinsic security features which is a challenge for lowering the document protection costs. Three types of papers were investigated using ESEM-EDS and ED(P)-XRFS in order to identify and characterize overt and covert intrinsic items. The paper shows that some of the intrinsic morphological features of document paper can be successfully used as taggants. The chemical compositions can be used as internal marks for forensic authentication of the ballpoint pen imprints. Two new ways are proposed for enhancing the document safety protection: the usage of the fractal dimension of the paper pattern and the intentional admixture into paper mass of cheaper substances as taggants in conjunction with SEM and XRF techniques.
\end{abstract}

Key words: counterfeiting, paper types, intrinsic security feature, forensic authentication

Nowadays, counterfeiting is a global problem [1-5]. A comprehensive analysis of the world trade reveals that at least $10 \%$ of banknotes / items are fakes or copies. A leading company acting on the anticounterfeiting market estimates that the world wide economic loss per year into UE is EUR 200-300 billion (Germany: EUR 29 billion) [6]. The current security taggants such as watermarks, holograms, including innovative chips or other sophisticated markers are considered effective solutions against counterfeiting, but they are expensive [5, 6, 8-12]. In this regard, the cost reduction of the security items designed to discriminate between genuine and counterfeit documents or products is the priority objective for the producers of goods or of valuable documents. A paper sheet has a unique fingerprint generated during its manufacturing e.g. microscopic bumps, pore and cracks, but specific chemical composition [13, 14]. The entire pattern of the microscopic material imperfections is impossible to be replicate on another medium [12, 15]. The literature offers a series of solutions for using the intrinsic codes of the products as covert tags, including paper for printing, writing or packaging [12, 15-17]. Practice shows that the code of each document paper is unique and can be read using a laser scanner or other specific devices $[5,12]$. Therefore, the intrinsic morphological codes of the papers can be powerful security items and can eliminate the need for chips, holograms or special ink. The general algorithm for document security protection based on paper codes consists in three steps [12]: 1) the document is scanned before being handed over to the owner; 2) the paper code is recorded in a database; 3 ) whenever the document holder is checked, the paper document is compared to the initial sample. Theoretically, this algorithm works, but some important factors could alter the accuracy, such as document aging, document crumbling, chemical heterogeneity and phase transformation under wetatmosphere or heating exposure $[18,19]$. These factors could compromise the genuine paper code and the document owner could be unfairly accused of using a tampered one. From this perspective, a current challenge on the battle front against document counterfeiting, tampering or forging is the usage of the intrinsic security features. In this direction, the paper addresses the identification of the intrinsic features of common and special papers using Scanning Electron Microscopy (SEM) and its Energy Dispersive Spectrometry (EDS) facility. SEM is the most appropriate technique for the observation of the morphological features at different magnifications while EDS provides the local elemental composition which can be another valuable intrinsic mark. The EDS analysis is carried out on an area of few square micrometers in size therefore, the EDS results are prone to significant uncertainties due to the intrinsic heterogeneity of the paper [20-25]. To bypass this issue, the X-ray fluorescence spectroscopy (XRFS) has to be used as it collect data on an area of about $20 \mathrm{~cm}^{2}$ and provides a representative average composition of the paper [26].

A paper specimen always contains certain amount of water and organic volatile substances that could impair the vacuum into the SEM specimen chamber. The Environmental SEM technique, denoted ESEM, has been used to avoid this draw back taking into account that ESEM can operate at higher pressure within the sample chamber, even with a certain humidity of the specimen as recent studies have demonstrated for biological samples [27-29].

The ED-XRFS spectrometers that use 3D geometry for specimen excitation, denoted ED(P)-XRFS, provide different excitation conditions ensuring optimum determination of the light to middle heavy elements due to the partial polarization of the exciting X-ray [26]. Accordingly, combined ESEM-EDS and ED(P)-XRFS investigation techniques have been used in order to identify the morphological features of the papers and to measure the elemental local compositions and the average ones. The study addresses the most uses common paper types and a document paper (DP) used for passport 
manufacture. The DP is a wood free paper, but may also contains cotton fibres, rags or it is fully made of cotton [5]. The DP has to preserve its morphology and colour for a long time i.e. it has to have a higher aging resistance [18, 19].

\section{Experimental part}

The main objective of the experimental part was to identify the intrinsic morphological and chemical marks of the most representative common paper types known as glossy white paper (GWP), common white paper (CWP) and a document paper (DP). At the same time the study has focused on the behaviour of the paper under ballpoint pen imprinting. The ESEM investigations were performed with a XL-30 ESEM instrument which uses a GSED stage to cope with a higher pressure into the specimen chamber. The XL-30 ESEM is equipped with a powerful EDS attachment that provides mass and atomic compositions of the selected area. The specimens for ESEM-EDS investigations do not need preparation but, ensuring their electrical discharge by gluing their back side with silver paste on specimen holder made of aluminium.

The ED(P)-XRFS measurements have been performed with a XEPOS bench-top spectrometer equipped with a $\mathrm{Rh} X$-ray tube and 3 secondary targets i.e. HOPG, corundum $\left(\mathrm{Al}_{2} \mathrm{O}_{3}\right)$ and Mo. The ED(P)-XRFS measurements do not need special specimen preparation i.e. just cutting disks of $40 \mathrm{~mm}$ in diameter and placing them into the XEPOS specimen holder. The $\mathrm{Rh}$ tube has been operated at $40 \mathrm{kV}$ and $1 \mathrm{~mA}$ and the achieved spectrometric data have been processed using Turboquant software.

\section{Results and discussions}

The morphology of the blank WGP and of the three ballpoint pen traces drawn on it are shown in figures 1.ad.. The images of the ballpointtraces in figure 1.a. highlight the pigment particles embedded in the organic paste. A detail of the cracks caused by the red ballpoint pen imprint marked in figure 1a. is shown in figure $1 b$. Figure $1 c$. has been obtained in Secondary Electrons mode (SE) while figure 1d. in Backscattered Electrons mode (BSE) which is more sensitive to the paper composition. The SE image reveals the morphological feature much better than BSE but, the BSE image reveals the chemical heterogeneity of the area under observation.

Figure 1.a., c, d., show that the morphology of the WGP is uneven, moreover figure 1.b., clearly shows a network of cracks around the red ballpoint pen line. Thus, the subsequent folding or bending of the paper can alter the initial configuration of cracks/crevices and surely can lead to the alteration of the genuine mark. Therefore, the above morphological features could not be used as intrinsic markers for WGP. The EDS spectra given by blank WGP and the ballpoint pen lines are shown in figure $2 a-d$.

The estimated mass concentrations corresponding to each spectrum obtained are given in table 1.

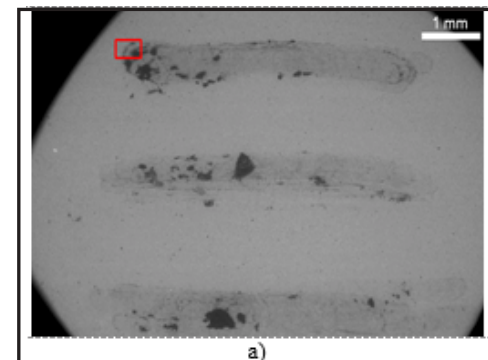

a)

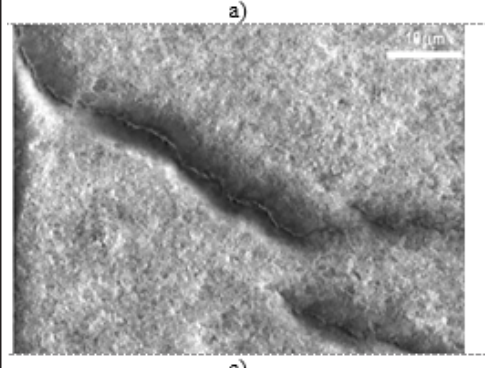

c)
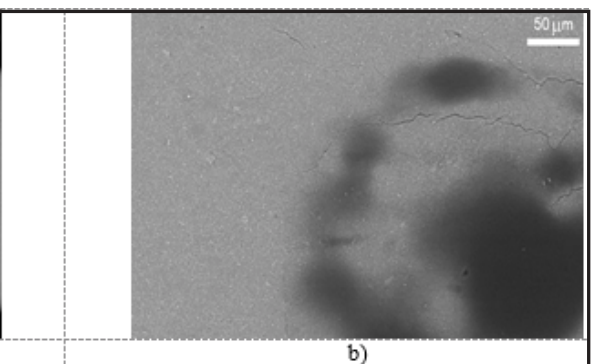

b)
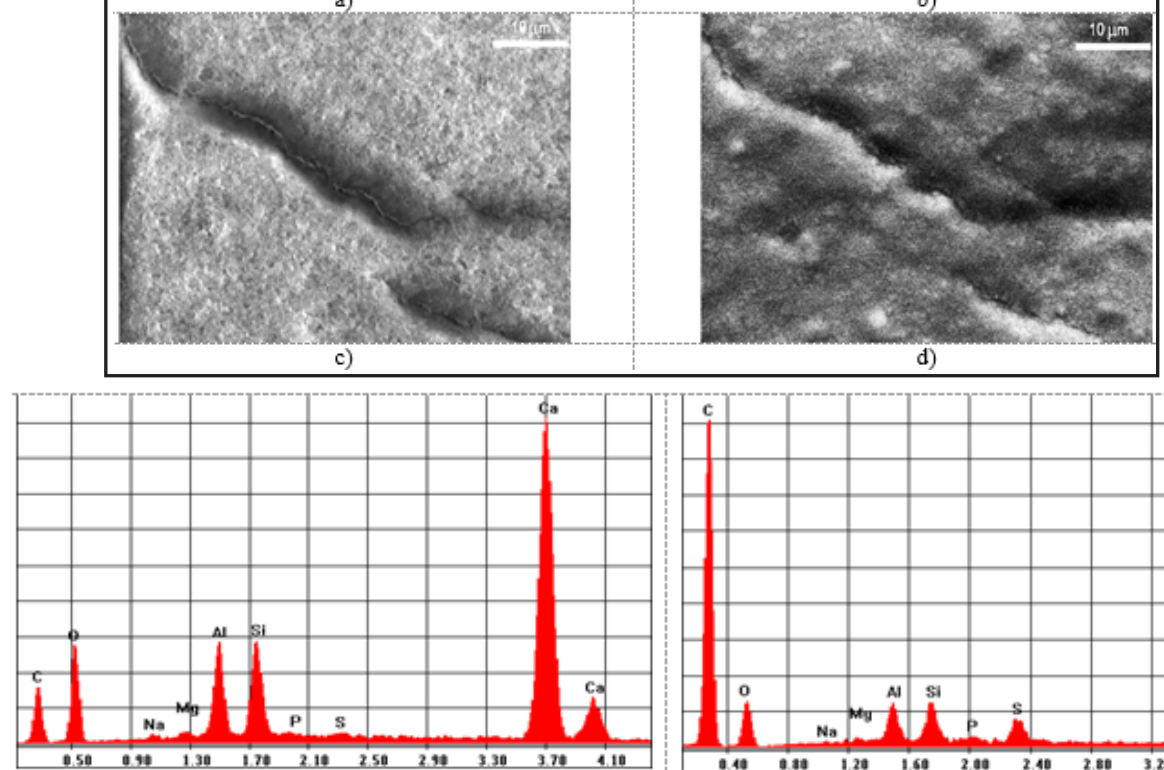

a)

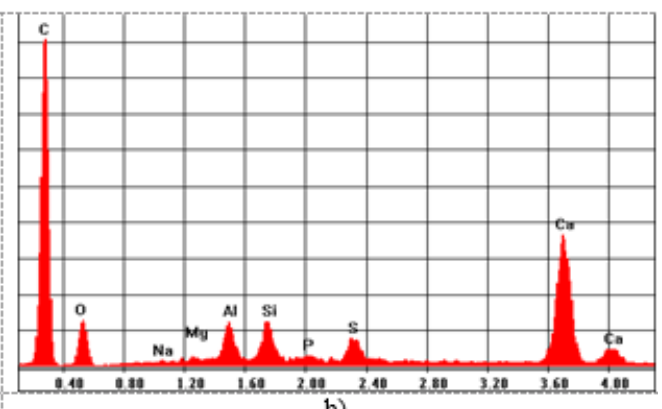

b)

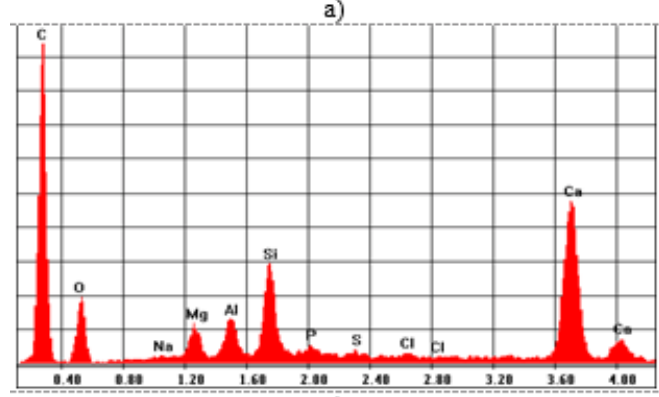

c)

REV.CHIM.(Bucharest) 69 No. 11 \2018

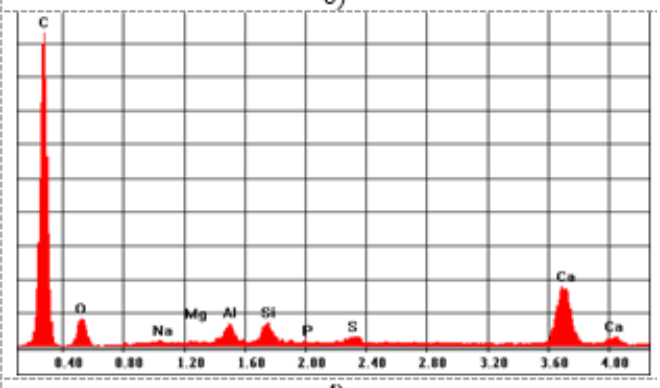

d)

http://www.revistadechimie.ro
Fig.1 ESEM image of the GWP morphology: a) red, blue 1 and blue 2 ballpoint pen tracks b) detail of paper cracking under ballpoint pen pressure c) SE image of a blank area;

d) BSE image of a blank area
Fig.2 EDS spectra of: a) blank WGP b) red ballpoint pen trace; c) blue 1 ballpoint pen trace d) blue 2 ballpoint pen trace 
Table 1

ELEMENTAL CONCENTRATIONS MEASURED BY EDS ON BLANK AND WRITTEN WGP AREAS

\begin{tabular}{|l|r|r|r|r|}
\hline $\begin{array}{l}\text { Element } \\
(\mathrm{wt} \%)\end{array}$ & $\begin{array}{l}\text { Blank } \\
\text { area }\end{array}$ & $\begin{array}{l}\text { Red } \\
\text { ballpoint } \\
\text { pen trace }\end{array}$ & $\begin{array}{l}\text { Blue 1 } \\
\text { ballpoint } \\
\text { pen trace }\end{array}$ & $\begin{array}{l}\text { Blue 2 } \\
\text { ballpoint } \\
\text { pen trace }\end{array}$ \\
\hline $\mathrm{C}$ & 13.57 & 59.06 & 52.51 & 66.39 \\
\hline $\mathrm{O}$ & 42.44 & 21.43 & 25.14 & 19.89 \\
\hline $\mathrm{Na}$ & 0.72 & 0.4 & 0.42 & 0.85 \\
\hline $\mathrm{Mg}$ & 0.09 & 0.06 & 0.25 & 0.06 \\
\hline $\mathrm{Al}$ & 0.27 & 0.1 & 0.1 & 0.08 \\
\hline $\mathrm{Si}$ & 6.48 & 2.51 & 5.07 & 1.96 \\
\hline $\mathrm{P}$ & 0.01 & 0.01 & 0.02 & 0.01 \\
\hline $\mathrm{S}$ & 0.43 & 1.85 & 0.5 & 0.98 \\
\hline $\mathrm{Cl}$ & 0.00 & 0.00 & 0.37 & 0.00 \\
\hline $\mathrm{Ca}$ & 35.99 & 14.59 & 15.62 & 9.78 \\
\hline
\end{tabular}

The EDS spectra and their assigned chemical compositions given in table 1 attest that the ball point pen lines can be chemically discriminated with a significant confidence level. The red and blue writing pastes are based on $\mathrm{C}$ filler as $\mathrm{C}$ content increases into ballpoint pen tracks while $\mathrm{Ca}$, Si and $\mathrm{Na}$ are masked. Accordingly, the particles in figure 1c, may be of carbon nature.

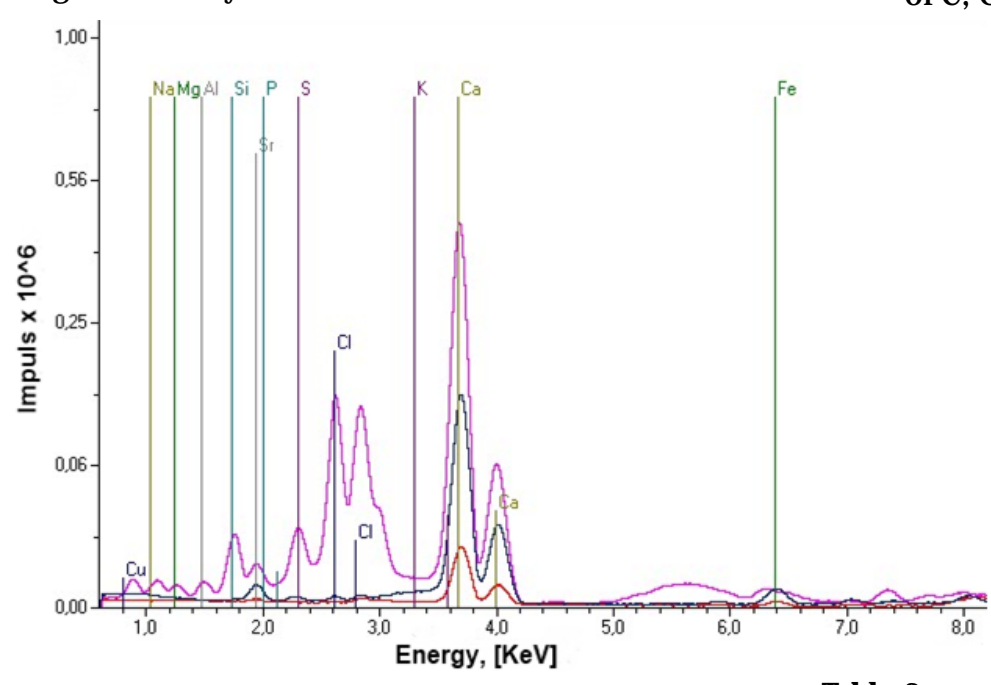

Table 2

THE ESTIMATED CHEMICAL COMPOSITION ASSIGNED TO FIGURE 3

\begin{tabular}{|c|c|c|c|c|c|c|c|c|c|c|c|}
\hline Element & $\mathrm{Na}$ & $\mathrm{Mg}$ & $\mathrm{Al}$ & $\mathrm{Si}$ & $\mathrm{P}$ & $\mathrm{S}$ & $\mathrm{Cl}$ & $\mathrm{Ca}$ & $\mathrm{K}$ & $\mathrm{Sr}$ & $\mathrm{Fe}$ \\
\hline$[w \mathrm{w} \%]$ & 0.78 & 0.08 & 0.26 & 6.52 & 0.011 & 0.41 & 0.33 & 36.01 & 0.13 & 0.01 & 0.01 \\
\hline
\end{tabular}
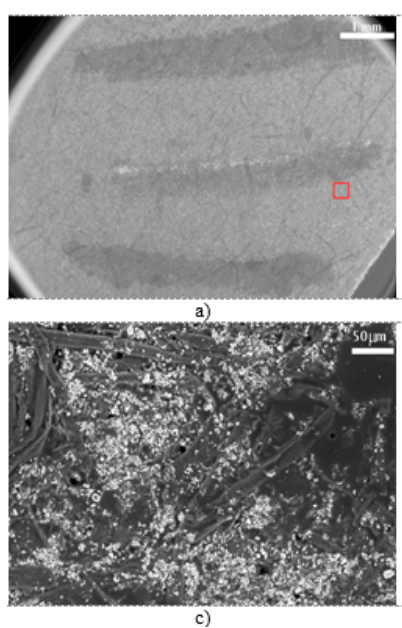
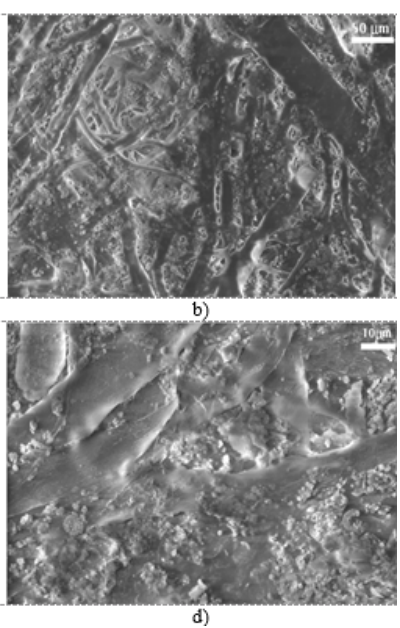

Fig 3. The ED(P)-XRFS spectra given by blank WGP
Fig 4. ESEM images of CWP morphology: a) image of the red, bluel and blue 2 ballpoint pen traces; $b$ ) details associated to c) image; c) bulk morphology; d) details associated to $c$ ) image
The ED(P)-XRFS spectra obtained on blank WGP are wigure 3. The red spectrum has been obtained the secondary Mo target, the blue one with $\mathrm{Al}_{2} \mathrm{O}_{3}$ and that the HOPG target is much more appropriate for the concentration measurement of the lighter elements i.e.

The chemicals responsive for the red and blue colors of the pastes are organic compounds as inorganic color fig. 2) and the ED(P)-XRFS measurements (fig. 3).

The CWP used for laser or ink printing, photocopying figure $4 a-d$.

As a general outcome revealed by figure 4 , the CWP consists of a mixture of mechanical paste as the main part, $\mathrm{CaCO}_{3}$ filler and wasted textile fibers. The fibrous fabric is quite evident as is shown in figure 4abd. The dried paste ched on the paper whiskers is clearly revealed in figure allpoint pen paste fig. 4d.).

The EDS spectra obtained on blank CWP and on the colpoint pen lines are shown in figure $5 a-d$. . The elemental composition assigned to the spectra shown in figure 5 is The 3.

The integral intensities of the $X$-ray characteristic lines of $\mathrm{C}, \mathrm{O}$ and $\mathrm{Ca}$ dominate all the spectra while those of $\mathrm{Na}$, 


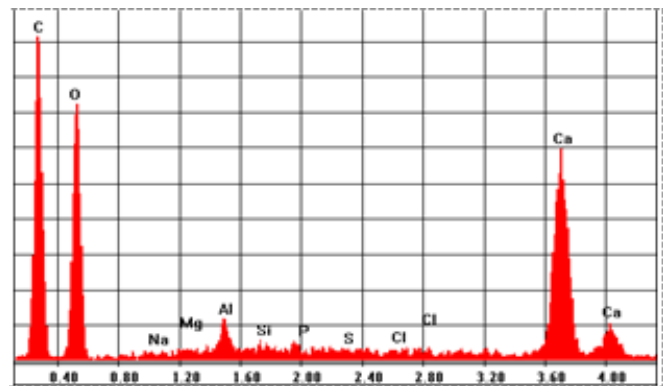

a)

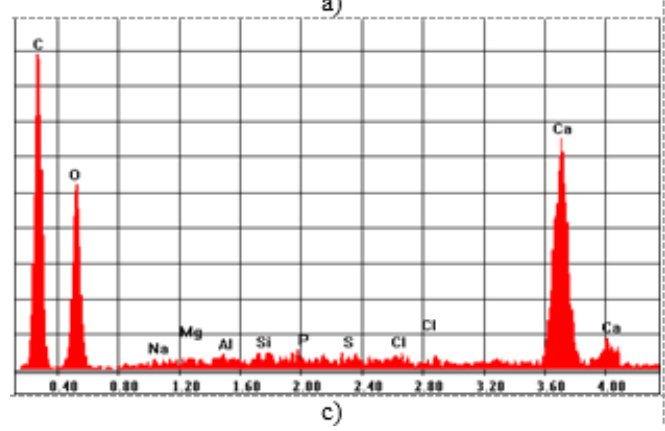

Table 3

THE EDS ELEMENTAL CONCENTRATIONS MEASURED ON BLANK CWP AND ON ITS IMPRINTED MARKS

\begin{tabular}{|l|r|r|r|r|}
\hline $\begin{array}{l}\text { Element } \\
\text { [wt\%] }\end{array}$ & \multicolumn{1}{l|}{$\begin{array}{l}\text { blank } \\
\text { CWP }\end{array}$} & $\begin{array}{l}\text { red ball } \\
\text { pen trace } \\
\text { on CWP }\end{array}$ & $\begin{array}{l}\text { blue 1 } \\
\text { ball pen } \\
\text { trace on } \\
\text { CWP }\end{array}$ & $\begin{array}{l}\text { blue 2 } \\
\text { ball pen } \\
\text { trace on } \\
\text { CWP }\end{array}$ \\
\hline $\mathrm{C}$ & 32.67 & 45.15 & 36.48 & 43.27 \\
\hline $\mathrm{O}$ & 50.78 & 43.41 & 44.80 & 41.96 \\
\hline $\mathrm{Na}$ & 0.53 & 0.72 & 0.56 & 0.45 \\
\hline $\mathrm{Mg}$ & 0.07 & 0.07 & 0.07 & 0.06 \\
\hline $\mathrm{Al}$ & 0.08 & 0.02 & 0.02 & 0.02 \\
\hline $\mathrm{Si}$ & 0.61 & 0.67 & 0.68 & 0.72 \\
\hline $\mathrm{P}$ & 0.01 & 0.01 & 0.02 & 0.02 \\
\hline $\mathrm{S}$ & 0.47 & 0.59 & 0.55 & 0.79 \\
\hline $\mathrm{Cl}$ & 0.48 & 0.68 & 0.62 & 0.65 \\
\hline $\mathrm{Ca}$ & 14.32 & 8.68 & 16.2 & 12.06 \\
\hline
\end{tabular}

Table 4

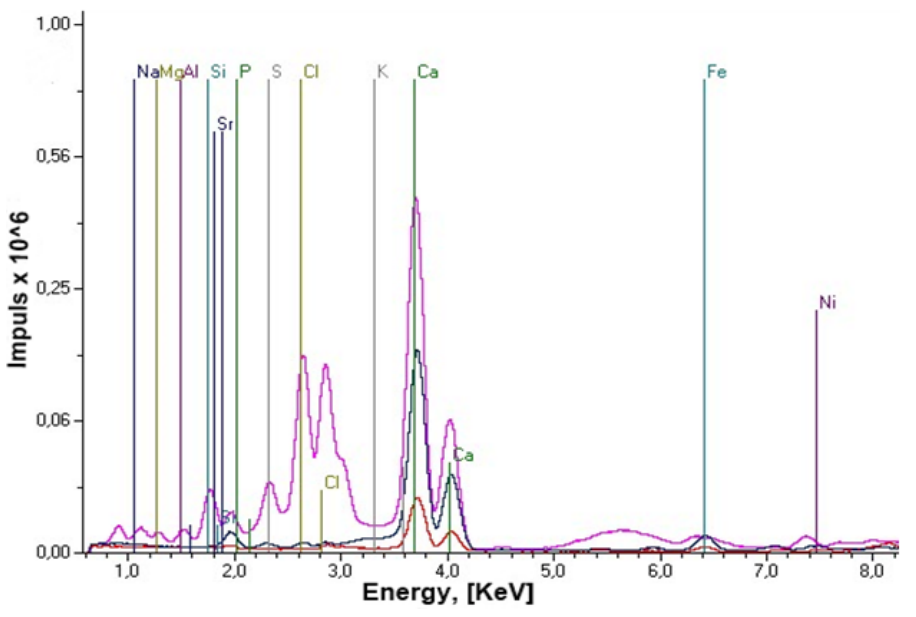

Fig. 6. EDP-XRFS spectra of the blank CWP

THE ESTIMATED ELEMENTAL COMPOSITION ASSIGNED TO FGURE 6

\begin{tabular}{|c|c|c|c|c|c|c|c|c|c|c|c|}
\hline Element & Na & Mg & Al & Si & P & S & Cl & Ca & K & Sr & Fe \\
\hline$[w \% \%]$ & 0.60 & 0.08 & 0.09 & 0.64 & 0.012 & 0.46 & 0.45 & 14.89 & 0.12 & 0.01 & 0.01 \\
\hline
\end{tabular}

$\mathrm{Mg}, \mathrm{Al}, \mathrm{Cl}, \mathrm{S}$ are peaked. The EDS spectra do not show the presence of $\mathrm{Fe}, \mathrm{Ni}$ and $\mathrm{K}$ while the XEPOS spectra (fig. 6) clearly reveal the $\mathrm{Fe}$ and $\mathrm{Ni}$ lines. The estimated elemental composition assigned to figure 6 is given in table 4 .

The values presented in table 3 shows that the EDS measurements clearly distinguish between the red and blue ballpoint pen pastes.

The chemical composition of the blank CWP measured by EDS and by ED(P)-XRFS are quite similar (table 3,4 ). The presence of $\mathrm{Fe}, \mathrm{Ni}$ and $\mathrm{Sr}$ can be assigned to the precursors of the paper and the presence of the unexpected elementcannotbe reasonably avoided. On the other hand, a controlled addition of a cheaper element into the paper bulk can be a valuable covert mark (table 3 ).

At a lower magnification, the morphology of a passport page (fig.7a.) is dominated by a blind raster embossed on a fibrous morphology. Ata higher magnification, the fibrous morphology of the passport paper is highlighted as can be seen in figure $7 \mathrm{~b}$. which shows a quite uniform morphological pattern. The stamped area and the associated
Fig.5. EDS spectra of: a) blank CWP, b) red ballpoint pen trace on $\mathrm{CWP} ; \mathrm{c}$ ) blue 1 ballpoint pen trace on CWP; d) blue 2 ballpoint pen trace on CWP signature are highlighted in figure $7 c$. The stamp preserves the paper morphological pattern while the signature draw alters the morphological pattern of the blank DP. Taking into account that the passport paper is a DP then the fibers shown in figure 7.b. are considered to be cotton.

The cotton fibers interweave in a complex way which can be considered of fractal nature. In this case, the fractal dimension, so called the FD parameter, of the fibrous pattern can be used as a quantitative covert safety taggant. The EDS spectra obtained on the blank area of a passportpaper, on the stamped area and on the signature imprint are shown in figure 8a-c. respectively. They show the peaks of the major elements $\mathrm{C}, \mathrm{O}, \mathrm{Ca}$ as in the cases of GWP and of CWP, but the contents of minor elements are different e.g. the spectra show the supplementary presence of Ti and $\mathrm{K}$ compared to the GWP and the CWP ones.

The elemental composition assigned to spectra shown in figure 8 are given in table 5 .

The chemical composition of the DP differs from the GWP and the CWP ones as it contains less $\mathrm{Ca}\left(\mathrm{CaCO}_{3}\right)$ and 


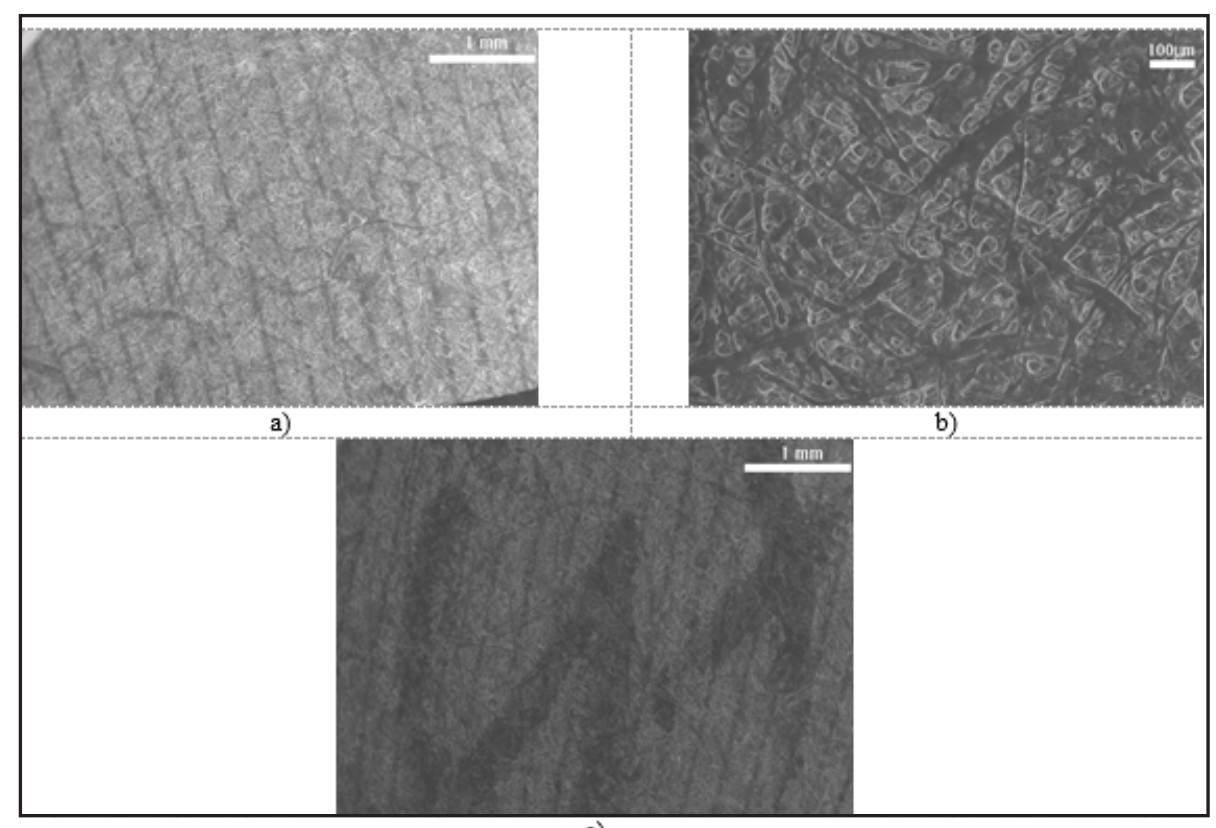

Fig. 7. ESEM images of the DP morphology: a) blank file; b) Details at higher magnification of the blank DP c) image of the stamped area and of the associated signature

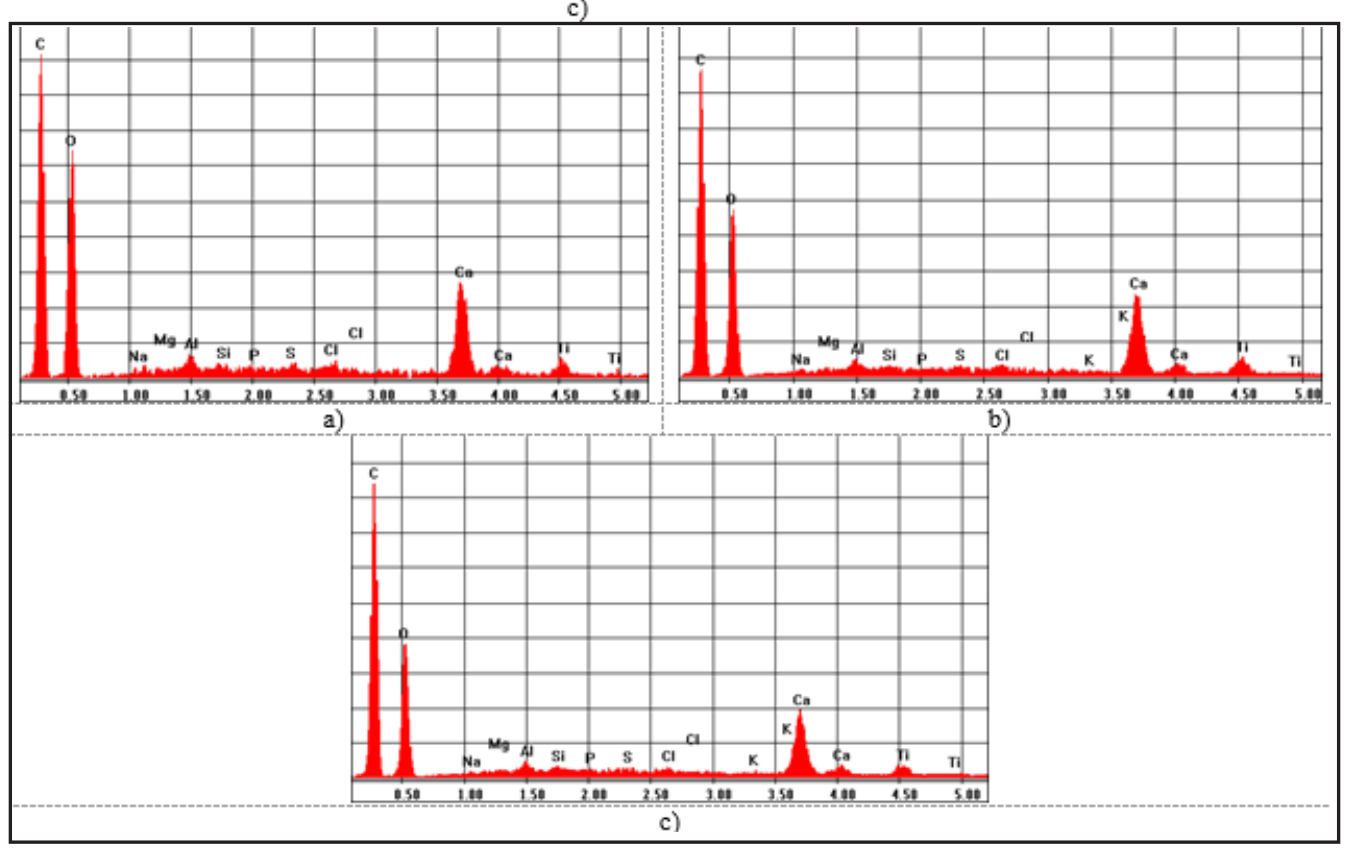

Fig.8. EDS spectra obtained on: a) blank DP, b) the stamp area; c) the signature imprint

Table 5

ELEMENTAL CONCENTRATIONS MEASURED BY EDS ON DP PAPER: A) BLANK AREA, B) STAMP AREA AND C) SIGNATURE IMPRINT

\begin{tabular}{|c|c|c|c|}
\hline $\begin{array}{c}\text { Element } \\
\text { [wt\%] }\end{array}$ & blank DP & $\begin{array}{c}\text { Stamp } \\
\text { area }\end{array}$ & $\begin{array}{c}\text { Signature } \\
\text { imprint }\end{array}$ \\
\hline $\mathrm{C}$ & 38.91 & 42.41 & 45.85 \\
\hline $\mathrm{O}$ & 49.14 & 45.09 & 43.22 \\
\hline $\mathrm{Na}$ & 0.06 & 0.73 & 0.59 \\
\hline $\mathrm{Mg}$ & 0.07 & 0.06 & 0.06 \\
\hline $\mathrm{Al}$ & 0.04 & 0.04 & 0.04 \\
\hline $\mathrm{Si}$ & 0.63 & 0.51 & 0.61 \\
\hline $\mathrm{P}$ & 0.02 & 0.01 & 0.01 \\
\hline $\mathrm{S}$ & 0.68 & 0.61 & 0.58 \\
\hline $\mathrm{Cl}$ & 0.84 & 0.73 & 0.60 \\
\hline $\mathrm{Ca}$ & 7.14 & 7.20 & 6.38 \\
\hline $\mathrm{Ti}$ & 1.87 & 2.28 & 1.75 \\
\hline $\mathrm{K}$ & - & 0.33 & 0.31 \\
\hline
\end{tabular}

more $\mathrm{Ti}\left(\mathrm{TiO}_{2}\right)$. The smaller content of $\mathrm{CaCO}_{3}$ as filler can be related to a better consistency of the cotton/rag mass, while a bigger content of $\mathrm{TiO}_{2}$ is aimed at improving the aging resistance and the whitening of the DP.

The EDP-XRFS spectra and the estimated average elemental composition assigned to the blank DP are given in figure 9 respective table 6.

Both ED(P)-XRFS and EDS measurements carried out on DP give similar outcomes. The compositions of the ballpoint pen imprint and of the stamp areas show an increased $C$ concentration while the other elemental concentrations are rather unchanged. Based on these outcomes one can consider that the ballpoint pen paste and the stamp ink are organic dyes. The EDS results emphases that the composition of the signature and stamp areas can not be used as forensic items. 


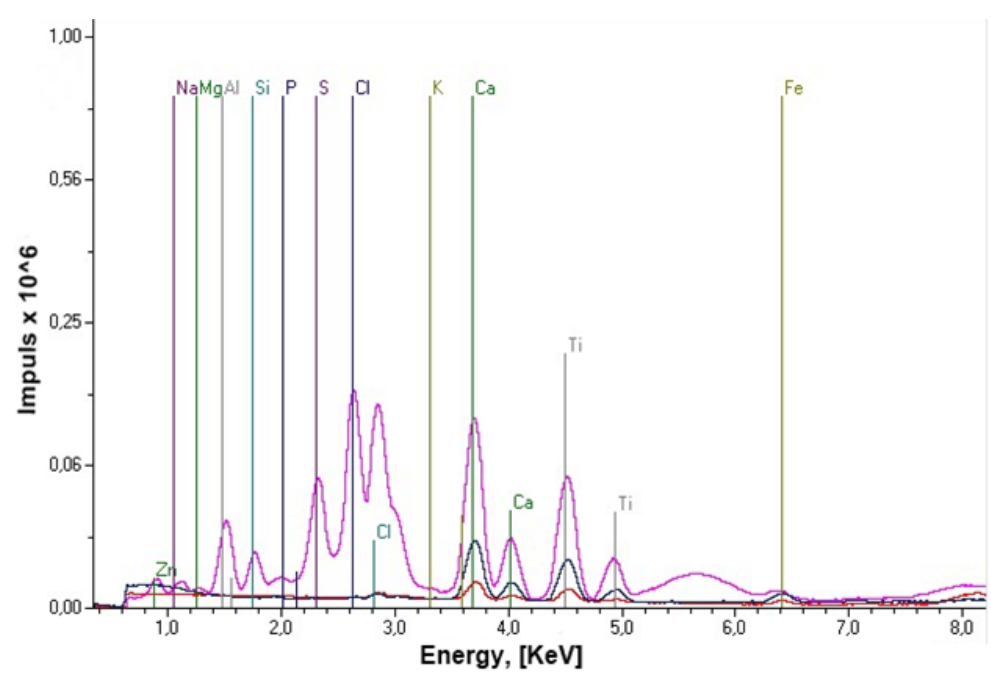

Fig.9. EDP-XRFS spectra and the estimated average elemental composition assigned to the blank DP

Table 6

THE ESTIMATED AVERAGE ELEMENTAL COMPOSITION ASSIGNED TO FIGURE 9.

\begin{tabular}{|c|c|c|c|c|c|c|c|c|c|c|c|}
\hline Element & $\mathrm{Na}$ & $\mathrm{Mg}$ & $\mathrm{Al}$ & $\mathrm{Si}$ & $\mathrm{P}$ & $\mathrm{S}$ & $\mathrm{Cl}$ & $\mathrm{Ca}$ & $\mathrm{Ti}$ & $\mathrm{K}$ & $\mathrm{Fe}$ \\
\hline [wt\%] & 0.64 & 0.05 & 0.05 & 0.68 & 0.019 & 0.71 & 0.13 & 7.17 & 1.90 & 0.02 & 0.015 \\
& & & & & & & & & & & \\
\hline
\end{tabular}

\section{Conclusions}

The morphological patterns of the GWP, CWP and DP show similarities i.e. fibrous patterns with complex interweaving.

The morphological features as crevices, cracks or pits identified into GWP and CWP cannot be considered as potential intrinsic security items, because subsequent folding or bending of the papers can alter the initial configuration of cracks/crevices and can surely lead to the disappearance of the genuine marks. In the case of DP, the morphology pattern is homogeneous and itcan be used as an intrinsic security feature.

The chemical compositions of the papers under consideration measured with EDS and ED(P)-XRFS are similar. The GWP and CWP have similar chemical compositions, therefore their chemical compositions cannot be considered as proper taggants but, the chemical compositions of the red and blue ballpoint prints can be used as forensic taggants.

The intentional admixture of a cheaper substance (ex. $\mathrm{Fe}_{2} \mathrm{O}_{3}, \mathrm{FeO}, \mathrm{Fe}_{3} \mathrm{O}_{4}, \mathrm{NiO}, \mathrm{TiO}_{2}, \mathrm{ZnO}$ etc.) into paper mass can be a powerful covert taggant when it is used in conjunction with an ED(P)-XRFS or a handheld XRF equipment.

The analysis of the morphological marks revealed by the ESEM investigations has led to the discovery of a new level for document security against counterfeiting, tampering and forging e.g. the FD parameter. The FD assessing of a document is a promising method as it is a fast one and can be cost effective and easily to implemented. In this respect, further studies have to be carried out to implement the box method using the ]-image freeware for assessing the FD of the documents [30, 31]

Acknowledgement: This work has been financially supported by the Romanian National Research Program code PN-III, subprogram P22.1-Bridge Grant, no. 0338/2016.

\section{References}

1.*** www.iacc.org/resources/about/what-is-counterfeiting/accessed on 2018.04.16

2.*** Report prepared for BASCAP and INTA, The Economic Impacts of Counterfeiting and Piracy, https://iccw bo.org/publication/economic- impacts-counterfeiting-piracy-report-prepared-bascap-inta/ accessed on 2018.04.16

3.*** Memorandum of Understanding on the online sale of counterfeit goods, http://ec.europa.eu/DocsRoom/documents/18023/attachments/ 1/translations/ accessed on 2018.04.16

4.*** FINDEISEN, A. M., AIGNER, S., Rare Earths and Their Use in High Security Printing: Security Pigments Out of Rare Earths and the AntiStokes Luminescence with Rare Earths in High-Security Printing at OeSD, SIAK-Journal Journal for Police Science and Practice (International Edition Vol. 3), 2013, p. 74-83, Online: http://dx.doi.org/ 10.7396/IE_2013_G

5.*** Hartiile de valoare - fabricatie, utilizare si protectie contra falsificarilor si contrafacerilor, Ed. Ceprohart, Stanciu C., Braila,2003, p.5-8,

6. CLAUTER, P., Merck - An Innovate and Reliable Partner offering Brand Protection Solution, applied in Printing \& Plastics, Merck KGaA, Darmstadt, Germany, www.easyfairs.com/ fileadmin/groups/ 10/ peter\%20clauter\%20R.pdf, accessed on 2018.04.16.

7.*** European Union (EU) Internet-Based Image Archiving System Known as FADO (False and Authentic Documents Online), http://eurlex.europa.eu/, accessed on 2018.04.16.

8.BURLACU, M., BUTEICA, D., SECARA, C., BRATU, G., DUMITRASCU I.,Special Inks for Security Printing, Rev.Celuloza si Hartie, 64, nr. 4, 2015, p. 23-31.

9.STRAT, M., BURUIANA, E., DUMITRIU, D., SANDU, A.V., GURLUI, S., Photophysical and Photochemical Properties of Polyurethane Coumarin Studied by Means of Electronic Spectra,Rev. Chim. (Bucharest), 68, no.7, 2017, p.1568-1572.

10.CONSTANTIN, C., BRATU, G., TALASMAN, C.M., Radu, A., BURLACU, M., DRAGAN, M., DUMITRASCU, I., CRACIUN, G.,Unconventional Fibrous Materials for PAPER SECURING, Rev. Celuloza si Hartie ,64, nr.3, 2015, p.24-40

11.BUTEICA, D., CONSTANTIN C., TÃCULESCU, A., SOCOLIUC, V., Research and Implementing of Securing Systems Aiming to Obtain the Value Document Security Paper Using Nanoparticles as Securing Elements, Rev. Celuloza si Hartie, 61, nr. 1, 2012, p.16-22

12.NECSOIU, T., BOSTAN, G., STERIAN, P., BERTEANU, M., Materials for Security Elements Used in Protected Documents, Optical Examination Methods. A Review. Annals of the Academy of Romanian Scientists Series on Science and Technology of Information ISSN 20668562 Volume 10, Number 1/2017.

13.NICA BADEA, D., Identification and Quantification of Active Principles of Products and Preparations for Tea and Coffee. Counterfeiting 
Detection of Beverages by Coupling with Extracts Xanthine TLC/GC/ MS, Rev. Chim. (Bucharest) 63, no.1, 2012, p. 10-13.

14.NICA BADEA, D., LEVAI, C., Separation and Detection of Caffeine, Theophylline and Theobromine from Coffee Varieties, Carbonated Soft Drinks and Alcoholic Beverages, Rev. Chim. (Bucharest),68, no. 11,2017, p. 2704-2707.

15.CLARKSON, W., WEYRICH T., FINKELSTEIN, A., HENINGER, N., HALDERMAN J . A., and FELTEN E.W., Fingerprinting Blank Paper Using Commodity Scanners Proc. IEEE Symposium on Security and Privacy, May 2009.

16.HENDRICK E., FREY, M., HERZ, E., WIESNER, U., Cellulose Acetate Fibers with Fluorescing Nanoparticles for Anti-counterfeiting and pHsensing Applications, Journal of Engineered Fibers and Fabrics Volume 5, Issue 1, 2010, p. 21-30.

17.YOU, M., ZHONG J., HONG, Y., DUAN, Z., LIN M., XU F., Inkjet Printing of Upconversion Nanoparticles for Anti-Counterfeit Applications, Nanoscale, 2015, 7, p.4423-4431 | 4423

18.ANDERS, M., BREDERECK, K., HABERDITZL, A., Mechanisms of Paper Ageing and Non - aqueous Paper Deacidification Combined with Paper Strenghtenings, 11-th Triennial Meeting Edimburgk, 1- 6 september 1996, Preprints Volume II, p. 481 - 487.

19.AREA, M.C., CHERADAME, H., Paper Aging and Degradation, 18. Recent Findings and Reseach Methods, Bioresurse J, vol. 6, issue 4, 2011, p. 5307-5337.

20.CALCERRADA, M., GARCIA-RUIZ, C. (2015). Analysis of questioned documents: a review. Analytica chimica acta, 853, 143-166.

21.MANSO, M., \& CARVALHO, M. L. (2009). Application of spectroscopic techniques for the study of paper documents: A survey. Spectrochimica Acta Part B: Atomic Spectroscopy, 64(6), 482-490.

22.BRANZEI, M., GHERGHESCU, I.A., CIUCA, S., Solder J oints Quality Assessment as Function of VPS Process Parameters, Rev. Chim.(Bucharest), 67, no.6, 2016, p. 1068-1072.

23.VASILESCU, V.G., VASILESCU, E., SEMENESCU, A., FLOREA, B., MATES, I.M., CHIVU O.R., Contributions Regarding the Influence of the Antibacterial Chemical Deposits on the Surface of the Oral Implant of the Ti10Zr Bio-Alloy on its Behaviour During Use, Rev. Chim.(Bucharest), 68, no. 2, 2017, p. 238-242.
24.ELLEN, D., The Scientific Examination of Documents, Methods and Techniques, Taylor \& Francis Ldt., Forensic Science Series, Salisbury, Wiltshire, 1997, p. 47-54.

25.MATTIUZZI, M., MARKOWICZ, A., A Modified Approach to Homogeneity Testing at Microscale, IAEA Laboratories Seibersdorf A2444 Seibersdoti Austria; International Centre for Diffraction Data 2000, Advances in X-ray Analysis, Vol.42.

26.PENCEA, I., Methods and Instrumental Techniques for Elemental Analysis of Materials, Chapter 8.2. in the Materials Science and Engineering Treaty, vol. 5, entitled Finished Processing Technologies of Metal Materials, Agir Publishing House, ISBN 978-973-720-391-5, Bucharest, 2011, pp. 1149-1151.

27. MICULESCU, F., MICULESCU, M., CIOCAN, L.T., PENCEA, I., ERNUTEANU, A., MATEI, E., Correlation of Spectometric Methods in Hard Tissue Heavy Elements Concentration Study, University Politehnica of Bucharest Scientific Bulletin-Series A-Applied Mathematics and Physics, Vol. 75, Iss. 1, Pag. 233-242. Document Type: Article. WOS:000315547300022, ISSN:1223-7027, 2013.

28.MAIDANIUC, A., MICULESCU, F., VOICU, S.I., ANDRONESCU, C., MICULESCU, M., MATEI, E., MOCANU, A.C., PENCEA, I., CSAKI, I., MACHEDON-PISU, T., CIOCAN, L.T. , Induced wettability and surfacevolume correlation of composition for bovine bone derived hydroxyapatite particles, Applied Surface Science, Volume: 438, Pages: 158-166DOI: 10.1016/j.apsusc.2017.07.074; WOS:000425731200017, ISSN: 0169-4332, 2018.

29.MICULESCU, F., CIOCAN, L.T., MICULESCU, M., BRANZEI M., GHIBAN, N., Thermal processing temperature influence on hard tissue chemical composition, Journal of Optoelectronics and Advanced Materials, Vol. 15, Iss. 7-8 Pag. 707-711, Document Type: Article, Accession Number: WOS:000323397900019, ISSN: 1454-4164, 2013. 30.**https://imagej.net/ accessed on 2018.04.17.

31.***PANIGRAHY, C., GARCIA-PEDRERO, A.G., G SEAL, A., ESPARRAGON, D.R., MAHATO N.K., MARTIN, C.G., An Approximated Box Height for Differential-Box-Counting Method to Estimate Fractal Dimensions of Gray-Scale Images, 2017, vol.19, issue 10, 534; doi:10.3390/e19100534 www.mdpi.com/journal/entropy

$\overline{\text { Manuscript received: } 22.05 .2018}$ 